\title{
DOXOLOGI, TRADISI REFORMED DAN MIMBAR: KONSEP ALLAH TRITUNGGAL DALAM PEMIKIRAN JONATHAN EDWARDS SEBAGAI BAGIAN DARI TRADISI PELAYANAN MIMBAR REFORMED
}

Jimmy Pardede

Gereja Reformed Injili Indonesia Bandung

\begin{abstract}
AbSTRAK: Jonathan Edwards' brilliant conception that combines disposition and being, and God's absolute being with dynamicity, has challenged the most commonly accepted classical greek dualism between being and becoming, and absolute and dynamicity. This conception was found in his Trinitarian view of creation. God's disposition to repeat His eternal glory was seen as one of the unique characteristic in Edwards' treatment on both his doctrine of the Trinity, and also his doctrine of creation. But this unique combination on disposition and being is also perfectly applicable in seeing the nature of preaching, repentance, and the spirituality of a true christian.
\end{abstract}

Kata KunCI: Trinity, being, becoming, disposition, glory, ad intra, ad extra. 


\section{Konsep Allah Tritunggal}

Konsep Allah Tritunggal Edwards hanya mungkin dimengerti melalui pemahaman konsep Being dan Becoming yang dikemukakannya. Konsep Edwards mengenai Being dan Becoming ini bukanlah suatu usaha untuk memadukan Heraklitus dan Parmenides, ${ }^{1}$ meskipun konsep Being Edwards pada naturnya merupakan suatu being yang memadukan konsep permanen dengan dinamis. Apa yang dilakukan Edwards adalah berusaha untuk mengemukakan suatu konsep yang menjelaskan tentang natur Allah di dalam keberadaan-Nya dan natur dunia yang mencerminkan Sang Penciptanya. Edwards melihat bahwa keberadaan itu sendiri merupakan sesuatu yang memiliki natur yang terus dalam proses becoming, tetapi yang juga adalah keberadaan aktual yang sempurna. Edwards mengemukakan suatu konsep yang melawan pengertian tentang Allah yang sebenarnya lebih dekat kepada konsep unmoved mover. Sang Hyun Lee mengemukakan bahwa konsep Allah yang diadopsi dari Aristoteles memiliki kesulitan untuk menjelaskan mengenai ciptaan. ${ }^{2}$ Ciptaan merupakan sesuatu yang tidak dapat dimasukkan ke dalam sistem dimana Allah adalah Allah yang absolut dan statis. Mengapakah Allah yang tetap, tidak berubah, dan absolut ini menciptakan dunia? Apakah Dia perlu mengaktualisasikan diri-Nya? Jika Dia masih perlu mengaktualisasikan diri-Nya dalam ciptaan, bukankah ini berarti Dia tidak sempurna? Ketidaksempurnaan ini terlihat dari keberadaan-Nya yang dalam keadaan berubah. Keberadaan Allah yang masih dalam suatu proses menunjukkan bahwa Allah bukanlah "Being" yang absolut, melainkan berada dalam proses "Becoming." Tetapi Edwards mengemukakan konsep yang menyatakan bahwa Allah memang berada dalam suatu proses "Becoming," namun tidak meniadakan "Being"-Nya yang sempurna. Edwards membahas keberadaan Allah sebagai Allah yang dinamis, tetapi juga absolut secara sempurna. Allah dalam konsep Edwards adalah sekaligus "Menjadi" atau "Becoming" dan juga "Aktual" atau "Being."3 Pemahaman yang dikemukakan oleh Edwards mengenai Allah yang adalah Being dan Becoming ini merupakan suatu pemahaman yang mendobrak pengertian bahwa Being merupakan suatu bentuk kesempurnaan yang statis sementara Becoming merupakan suatu bentuk ketidaksempurnaan yang secara dinamis terus berproses menuju kesempurnaan dengan menunjukkan bahwa natur ontologism Allah adalah Being sekaligus Becoming. Bagi Edwards Allah memiliki suatu disposisi yang merepetisi diri-Nya sendiri. Konsep inilah yang, menurut Lee, harus dianggap sebagai konsep dasar untuk memahami seluruh pemikiran

Sang Hyun Lee, The Philosophical Theology of Jonathan Edwards. New Jersey: Princeton University Press, 1988. p. 96.

2 Ibid., p. 4.

$3 \quad$ Ibid., p. 6. 
filosofis teologis Edwards. ${ }^{4}$ Allah berada dalam suatu proses untuk merepetisi diri-Nya secara kekal tetapi dengan kesempurnaan aktualitasNya yang tidak terbatas, kekal, tidak berubah, dan dengan kemuliaan dan sukacita-Nya yang sempurna. ${ }^{5}$

Repetisi yang dimaksudkan adalah repetisi dari Allah Bapa, Sumber dari segala sesuatu, dimana kedua Pribadi yang lain berasal. Pemahaman ini merupakan pemahaman yang digunakan Edwards untuk memahami natur dari seluruh ciptaan alam semesta ini. Dari Bapa lahir Pribadi Kedua, dan dari Bapa keluar Pribadi Ketiga. Namun konsep ini harus dimengerti bukan sebagai pembedaan temporal, yaitu pengertian bahwa ada periode dimana Pribadi Pertama ada tanpa adanya Pribadi yang lain, lalu ada suatu waktu tertentu dimana Pribadi Kedua lahir dari Pribadi Pertama. Keberadaan Allah adalah kekal dan sempurna. Keberadaan-Nya merupakan keberadaan yang "unoriginated," dan ini merupakan keberadaan yang dimiliki baik oleh Pribadi Pertama maupun Pribadi Kedua dan Ketiga. Keberadaan yang demikian ini merupakan keberadaan Allah sebagaimana dipahami oleh Edwards. ${ }^{6}$ Tetapi, untuk memahami natur disposisional Allah, kita harus melihat keberadaan Allah dengan memberikan suatu pembedaan logis, yaitu pembedaan yang perlu dilakukan untuk memahami penjelasan diatas mengenai keberadaan Pribadi Kedua dan Pribadi Ketiga, ${ }^{7}$ dimana proses tersebut merupakan sesuatu yang diperlukan agar pemahaman kita, yang tidak dapat lepas dari konsep pembedaan temporal, boleh memiliki gambaran untuk menangkap analogi yang digunakan Edwards. Edwards mengemukakan keberadaan tiga Pribadi Allah sebagai suatu pembedaan logis dengan menggunakan analogi keberadaan psikologis manusia. Analogi ini dinamakan analogi psikologis dari Allah Tritunggal, yang, menurut Lee, mengambil contoh dari analogi seorang manusia dari John Locke. ${ }^{8}$ Pribadi Pertama merepetisi diri-Nya secara sempurna dalam keberadaan Pribadi Kedua yang adalah "intellectual exercise of the Father's disposition" Karena itu Pribadi Kedua merupakan "God's perfect Idea of Himself". Dan demikian pula konsep repetisi diberikan untuk memahami Pribadi Ketiga. Dalam analogi ini Pribadi Ketiga adalah: "God's love of God's own idea of himself as well as the self-communication or self-

\footnotetext{
4 Lihat dalam pembahasan Lee dalam buku yang sama, misalnya pp. 4, 9, 108. Pendapat ini, meskipun dinyatakan dalam perspektif "relasional," juga adalah pendapat dari Amy Plantinga Pauw dalam bukunya: The Supreme Harmony of All: The Trinitarian Theology of Jonathan Edwards. Grand Rapids: Eerdmans, 2002,p. 120.

5 Lee, "Jonathan Edwards's Dispositional Conception of the Trinity," dari Toward the Future of Reformed Theology: Tasks, Topics, Traditions. David Willis, Michael Welker, ed. Grand Rapids: Eerdmans, 1999. p. 448.

$6 \quad$ Ibid., p. 450.

$7 \quad$ Ibid., p. 451.

$8 \quad$ Ibid., p. 449. John Locke menjelaskan keberadaan psikologis manusia sebagai berikut: Diri, ide refleksif dari diri mengenai diri, dan diri yang mencintai ide refleksif dari diri.

9 Ibid.
} 
repetition of God in an affectional exercise of the divine disposition."10

Keberadaan ini merupakan keberadaan yang berproses namun juga aktual secara sempurna, dan natur keberadaan Allah inilah yang dilihat oleh Edwards sebagai suatu keberadaan yang dapat menjelaskan mengenai keberadaan seluruh alam ciptaan ini. Keberadaan Allah Tritunggal ini disebut dengan repetisi ad intra. Prinsip ini, menurut Edwards, merupakan suatu prinsip yang menggambarkan natur dari seluruh alam ciptaan ini. Konsep penciptaan merupakan suatu repetisi ad extra dari repetisi disposisi (atau natur keberadaan) dari Allah secara ad intra. Tetapi keberadaan menjadi sesuatu yang tidak bermakna kecuali dalam memahami konsep Tritunggal, seseorang juga memahami harmonisasi yang ada dalam hubungan antar Pribadi dalam Tritunggal. Ketiga Pribadi dalam Allah Tritunggal memiliki suatu harmonisasi keberadaan yang sempurna, yaitu yang menyatakan kemuliaan Allah sendiri. Inilah yang disebut dengan "God's internal self glorification" "11 Allah mempermuliakan diri-Nya sendiri dengan dua cara, yaitu, sebagaimana dikatakan oleh Holmes: “...in knowing Himself in His own perfect idea, the Son, and in flowing forth in love and delight for Himself -the Spirit."12 Konsep Edwards dalam melihat aktivitas penciptaan dunia ini oleh Allah, yang, sebagaimana telah dijelaskan sebelumnya, adalah suatu bentuk ad extra dari aktivitas yang dilakukanNya ad intra, merupakan konsep yang sama yang diterapkan untuk melihat tujuan dari penciptaan dunia ini oleh Allah, dimana konsep God's internal self glorification ini diadopsi menjadi suatu bentuk ad extra yang menyatakan kemuliaan Allah. God's internal self glorification merupakan suatu ad intra dimana penyataan kemuliaan Allah di dalam dan melalui ciptaan adalah ad extra. Sebelum kita membahas bagian ini lebih dalam, mari kita lihat pengertian Edwards mengenai natur dari karya Roh Kudus.

\section{Konsep Roh Kudus}

Pneumatologi Edwards adalah konsep yang memakai peran Roh Kudus dalam relasi intra Allah Tritunggal sebagai dasar Edwards seringkali mengaitkan natur dari karya Roh Kudus sebagai cinta dari Pribadi Pertama terhadap Pribadi Kedua, ${ }^{13}$ pemberi cinta kasih Allah kepada orang percaya," "the bond of love between the Father and Son", 15 komunikasi cinta kasih antar Pribadi Tritunggal, ${ }^{16}$ ataupun komunikasi cinta kasih

\footnotetext{
10 Ibid.

11 Stephen R. Holmes, God of Grace and God of Glory. Grand Rapids: Eerdmans, 2000. p. 41.

12 Ibid.

13 Lee, Jonathan Edwards's Dispositional Conception of the Trinity. p. 449.

14 Amy Plantinga Pauw, The Supreme Harmony of All: The Trinitarian Theology of Jonathan Edwards. Grand Rapids: Eerdmans, 2002. p. 13.

15 Ibid., p. 49.

16 Nichols, An Absolute Sort of Certainty: The Holy Spirit and the Apologetics of Jonathan Edwards. New Jersey: Presbyterian \& Reformed, 2003. p. 35.
} 
antara Allah dan ciptaan-Nya. ${ }^{17}$ Tetapi Stephen Nichols menyimpulkan bahwa salah satu konsep Edwards mengenai karya Roh Kudus adalah sebagai Pribadi yang “...reveal(ing) the Trinity ad extra." 18

Karya Roh Kudus dalam menyatakan Tritunggal ad extra akan lebih jelas bila kita meneliti kembali konsep Edwards yang menempatkan Pribadi Ketiga sebagai Pribadi yang menyatakan cinta kasih Pribadi Pertama akan repetisi diri-Nya secara intelektual dan sempurna, yaitu Pribadi Kedua. Dengan demikian, dalam komunikasi dan hubungan personal dalam Tritunggal, Pribadi Ketiga merupakan Pribadi yang adalah kasih, peninggian, dan pemuliaan dari Pribadi Pertama bagi Pribadi Kedua. Allah Bapa meninggikan Anak, mengasihi Anak, dan mengirim Roh Kudus-Nya untuk menyatakan kemuliaan dari Sang Anak karena demikianlah natur dari Pribadi Ketiga dalam komunikasi intra Allah Tritunggal. Dalam keharmonisan yang sempurna, Allah menyatakan kemuliaan-Nya ad intra dengan meninggikan Pribadi Kedua. Pribadi Kedua tidak meninggikan diriNya sendiri, tetapi Pribadi Pertama dan Ketiga, dalam keharmonisan yang sempurna, meninggikan Anak, yaitu Pribadi Kedua, sebagai repetisi sempurna dari ide diri Pribadi Pertama.

Ketika Roh Kudus menyatakan pekerjaan-Nya dalam dunia, berarti Dia menyatakan natur-Nya yang meninggikan Pribadi Kedua dalam suatu karya ad extra. Roh Kudus memberikan assurance akan keselamatan jiwa seseorang karena Roh Kudus mengungkapkan kemuliaan Kristus memenuhi seseorang. ${ }^{19}$ Roh Kudus memberikan suatu keyakinan akan otoritas Kitab Suci dengan menunjukkan bahwa Kitab Suci meninggikan Pribadi Anak Allah. ${ }^{20}$ Inilah konsep Edwards mengenai natur dari karya Roh Kudus. Dengan konsep ini kita akan melihat karya penciptaan yang dilakukan Allah menurut konsep Edwards.

\section{Konsep Allah Tritunggal dan Penciptaan}

Sang Lee mengatakan bahwa Edwards telah melampaui konsep tradisional Barat mengenai substance dan form. Dia mengatakan bahwa "Edwards departed from the traditional Western metaphysics of substance and form and replace it with a strikingly modern conception of reality as a dynamic network of dispositional forces and habits. ${ }^{21}$ Tentu saja ini hanya dapat terjadi karena Edwards melihat realita keberadaan Allah sebagai realita yang ultimat dimana segala sesuatu yang lain merupakan realita yang dapat dipahami dengan menempatkannya sebagai suatu realita derivatif. Realita derivatif yang dapat dipahami sebagai sesuatu yang mencerminkan

17 Ibid., p. 83.

18 Ibid., p. 36.

19 Nichols, An Absolute Sort of Certainty. p. 162.

20 Ibid.

21 Lee, The Philosophical Theology of Jonathan Edwards. p. 4. 
Sang Pencipta dan dengan mengaitkannya sebagai ciptaan yang diciptakan oleh Allah. Konsep Trinitarian Edwards dalam melihat ciptaan, yaitu dengan mengaitkan penciptaan sebagai karya ad extra dari apa yang Allah kerjakan ad intra, merupakan suatu konsep yang dapat menjelaskan mengapa Allah menciptakan dunia. Allah yang dipahami secara disposisional, yaitu Allah yang memiliki suatu disposisi yang sekaligus dinamis, tetapi juga sekaligus sebagai aktualitas sempurna, tidak perlu mengompromikan kesempurnaan dan kepenuhan-Nya untuk menciptakan dunia ini. Keberubahan Allah tidak harus diterima dengan mengompromikan kesempurnaan keberadaan-Nya, sebagaimana dijelaskan oleh Edwards, dan dijabarkan Sang Lee, "God is essentially a perfect actuality as well as a disposition to repeat that actuality through further exercises." 22

Dengan konsep ini, ciptaan dipahami sebagai suatu karya yang merepetisi kemuliaan Allah. Repetisi kemuliaan Allah secara ad intra, sebagaimana dijelaskan sebelumnya, terjadi (dengan melihatnya secara pembedaan logis, tentunya) dengan repetisi kesempurnaan ide dari Allah Bapa dalam Allah Anak, dan repetisi dalam kesempurnaan delight dari Allah Bapa kepada Allah Anak dalam diri Allah Roh Kudus. Repetisi ini juga, yang dikerjakan ad extra, merupakan repetisi yang dikehendaki Allah untuk terjadi dalam dunia (tidak lagi secara pembedaan logis saja, tetapi juga pembedaan temporal). Tetapi bila dalam ad intra terjadi kesempurnaan repetisi, maka dalam ad extra tentu akan dibutuhkan waktu yang tak terbatas bagi yang terbatas ini untuk mencapai repetisi sempurna dari Allah yang tak terbatas. Karena itulah keberadaan ciptaan ini tidak akan berakhir, tetapi akan terus menerus berproses menuju kesempurnaan tanpa pernah mencapai kesempurnaan tersebut. Maka itu Edwards, sebagaimana dikatakan Lee, memiliki pengertian akan kerajaan Allah yang termanifestasi secara terus menerus dan melampaui sejarah dunia ini. Kerajaan Allah adalah suatu tujuan ultimat yang bersifat imanen dan juga melampaui imanensi. ${ }^{23}$ Dengan konsep ini, Edwards melihat realita sebagai suatu perpaduan antara being tetapi juga becoming, sebagaimana dikatakan Lee,

Reality, for Edwards, is an ordered tendency. To the extent that a disposition has permanence as an abiding real-ness apart from its actual operation and as a structured or ordered power, being is essentially permanent. At the same time, since a disposition is a power with causal efficacy, being, defined dispositionally, is becoming. ${ }^{24}$

Sebab itu, konsep Edwards ini bukanlah dikemukakan untuk menjawab 
pertanyaan mengenai apakah realita itu tetap atau berubah. ${ }^{25}$ Edwards melihat lebih dalam lagi dengan berusaha menjawab, apakah tujuan dari keberadaan ini dalam keseluruhan rencana Allah? Dan apakah delight yang Allah dapatkan dari keberadaan penciptaan ini? Pencarian yang telah bergerak melampaui Parmenides dan Heraklitus ini mendapatkan jawabannya pada konsep dispositional ontology dari Allah Tritunggal. Namun, jawaban yang diberikan Edwards ini juga menyelesaikan pertentangan being dan becoming ini dengan memberikan suatu alternatif yang, menurut Lee, ternyata merupakan konsep yang melampaui zamannya dengan sebuah "strikingly modern conception of reality." ${ }^{26}$ Keberadaan dalam konsep Edwards ini dilihat, pada dasarnya, sebagai "ordered power combines the dynamic with the permanent." ${ }^{, 27}$ Namun, meskipun pencapaian ini merupakan pencapaian yang melampaui zamannya, tetapi yang lebih menarik perhatian Edwards dalam melihat natur dasar dari penciptaan, melampaui perdebatan filosofis pada masanya, adalah natur becoming dari realita disposisional ciptaan ini. Edwards memperoleh suatu bentuk yang konsisten atas pemahamannya ini dengan fokus dari pemikiran teologisnya pada konsep The Glory of God. ${ }^{28}$

Pemahaman ini pertama-tama dibahas Edwards dalam bentuk wahyu umum. Keseluruhan ciptaan ini menyatakan keindahan Sang Pencipta. Dalam seluruh keharmonisan alam, keindahan, ketelitian, kekuatan, dan segala yang terdapat pada alam, terdapat suatu pernyataan untuk memberikan konfirmasi bagi kemuliaan Allah. Namun, kemuliaan Allah yang dinyatakan melalui ciptaan ini, atau, untuk lebih terdengar Edwardsean, Kemuliaan Allah yang direpetisi dalam ciptaan ini, merupakan suatu konsep yang sulit dipadukan dengan konsep "Divine Simplicity," jika "Divine Simplicity" itu disalahmengerti sebagai simplisitas realita yang satu dan tetap a la Parmenides. Sebagaimana dikemukakan oleh Pauw:

Beauty thus requires complexity. Within the divine simplicity tradition, complexity was a mark of creaturely limitation. Edwards practically reversed this, finding creaturely limitation reflected in the incapacity for complexity. ${ }^{29}$

Keindahan dalam dunia ini mengomunikasikan kemuliaan Allah, ${ }^{30}$ dan karena itu usaha memahami natur disposisional dari dunia ini, yang

\footnotetext{
25 Ibid.

26 Ibid., p. 4.

27 Ibid., p. 96.

28 Konsep yang dilihat oleh, misalnya, Stephen Holmes dalam God of Grace and God of Glory (Grand Rapids: Eerdmans, 2000). Meskipun dalam pembahasannya Holmes sepertinya lebih melihat Edwards sebagai seorang "Barthian," namun penekanan Edwards yang begitu jelas dalam konsep Glory mewarnai pembahasan Holmes mengenai konsep penciptaan (meskipun dia sedikit mengalami masalah dalam membahas konsep murka Allah dalam pemikiran Edwards yang "Barthian").

29 Pauw, The Supreme Harmony of All. p. 81.

30 Ibid., p. 83.
} 
memiliki sisi kompleks dari sifatnya yang terus berubah, mencerminkan natur Allah yang juga memiliki keberubahan yang merepetisi diri demi manifestasi kemuliaan-Nya; suatu konsep yang tidak mendapat tempat dalam pemahaman akan Allah yang secara kaku tidak berubah, tetapi juga tidak dapat disamakan dengan keberubahan yang tanpa aktualisasi sempurna, sebab, sebagaimana dinyatakan oleh Edwards, Allah adalah aktual secara sempurna, dan juga terus dalam proses becoming. ${ }^{31}$

\section{Kemuliaan Allah Sebagai Tujuan Penciptaan}

Dalam pemikiran Edwards, Allah mengomunikasikan kemuliaan-Nya secara ad extra dalam dua cara, yaitu dikenal oleh ciptaan-Nya; dan dikasihi, serta dinikmati oleh seluruh ciptaan-Nya. ${ }^{32}$ Kemuliaan ini dinyatakan ketika ciptaan merasakan limpahan kasih-Nya. Kasih yang secara sempurna dinyatakan dalam Pribadi-pribadi intra Allah Tritunggal. Konsep Edwards ini memelihara pandangan yang melihat pemberian dari Allah kepada ciptaan, yang merupakan suatu pemberian yang keluar dari hubungan intra-Trinitarian, dan dengan demikian memahami konsep aseity dengan secara seimbang mempertahankan pengertian mengenai sukacita dalam diri Allah ketika Dia memberi. ${ }^{33}$ Ini merupakan sesuatu yang sangat jelas ditekankan oleh Edwards. Misalkan dalam disertasinya mengenai mengapa Allah menciptakan dunia:

Because it is evident, by both Scripture and reason, that God is infinitely, eternally, unchangeably, and independently glorious and happy: that he cannot be profited by, or receive any thing from, the creature... ${ }^{34}$

Kesempurnaan Allah merupakan kesempurnaan yang mendasari pengertian kita akan kecukupan Allah pada diri-Nya sendiri. Pengertian ini menjadi konsep dasar yang harus diterima sebelum melanjutkan pengertian Edwards mengenai bagian ini.

Dengan memahami konsep aseity Allah, maka, jika demikian, alasan Allah menciptakan dunia ini menjadi tidak jelas, bila tidak digabungkan dengan mengingat konsep penciptaan menurut Edwards, dimana konsep penciptaan berada dalam karya ad extra Allah Tritunggal. Maka, dalam disertasinya mengenai mengapa Allah menciptakan dunia, Edwards mengatakan bahwa Allah hanya mungkin menjadikan diri-Nya sendiri tujuan dari penciptaan ini. Konsep ini menjadi jelas dengan alasan yang dikemukakan Edwards sendiri. Edwards menulis: "Hence it will follow, that

\footnotetext{
31 Kembali ke pembahasan pada halaman pertama tulisan ini.

32 Lihat pembahasan Holmes, God of Grace and God of Glory. p. 41.

33 Ibid., p. 42.

34 Jonathan Edwards, The End for which God Created the World, dari The Works of Jonathan Edwards, 2 vol, Massachusetts: Hendrickson Publishers, 2000. p. 97.
} 
the moral rectitude of the disposition, inclination, or affection of God CHIEFLY consists in a regard to HIMSELF, infinitely above his regard to all other beings..." ${ }^{, 35}$ Dengan pengertian ini, Allah tidak mungkin memiliki tujuan penciptaan diluar diri-Nya sendiri, sebab segala keindahan dan kesempurnaan moral Allah adalah yang sempurna, yang ilahi, dan yang tidak terbatas. Bagaimanakah ada apapun dalam realm ciptaan yang dapat menyamai Dia? Dengan demikian, maka memang Allah harus menjadikan diri-Nya sendiri tujuan dari seluruh ciptaan ini. Konsep ini berbeda dengan pengertian Aristoteles mengenai rasio sempurna yang tidak dapat menyadari apapun diluar dirinya. Karena ia adalah sempurna, maka kesadaran dirinya hanya tertuju pada kesempurnaan, yaitu dirinya sendiri. Tetapi tidak demikian pemahaman Edwards akan Allah. Allah menyadari keberadaan ciptaan dan menciptakan seluruh keberadaan ciptaan-Nya dengan tujuan untuk berfokus kepada Dia. Dialah "Chief End" dari ciptaan ini.

Edwards menjelaskan lebih dalam lagi mengenai konsep penciptaanNya dengan menambahkan bahwa Allah memiliki keinginan untuk menyatakan kepenuhan-Nya yang tidak terbatas dengan cara menciptakan. Hal ini merupakan suatu...

...disposition in God, as an original property of his nature, to an emanation of his own infinite fullness, was what excited him to create the world; and so, that the emanation itself was aimed at by him as a last end of the creation. ${ }^{36}$

Dan pernyataan kepenuhan-Nya tersebut dilakukan-Nya dengan mengomunikasikan pengenalan akan diri-Nya, sehingga kepenuhan ciptaanNya berada pada pengenalan akan Dia sebagai Pencipta. Edwards mengatakan: "One part of that divine fullness which is communicated, is the divine knowledge which must be supposed to pertain to God's last end in creating the world, is the creature's knowledge of HIM." ${ }^{\prime 37}$ Pengenalan akan Allah menjadi suatu konsep yang sangat penting bagi Edwards untuk manusia dapat menyadari kemuliaan Allah. Ini berbeda dengan anggapan golongan-golongan Kristen yang menekankan perasaan secara berlebihan tanpa memiliki konsep yang konsisten, yang merasa bahwa Edwards adalah bapak iman mereka, padahal jelas sekali bahwa Edwards menekankan pengenalan secara konseptual dan konsisten; mulai dari natur Allah sebagai dasar keberadaan, dan keberadaan dunia ini, dimana semuanya dilihat sebagai satu kesatuan yang konsisten dan dapat dipertanggungjawabkan; hingga pengertiannya mengenai pernyataan kemuliaan Allah yang diawali dengan pengenalan akan Dia.

Selain menekankan pengenalan akan Allah, Edwards mengatakan

35 Ibid., p. 98 (Penekanan dari Edwards).

36 Ibid., p. 100.

37 Ibid., p. 101. 
bahwa tujuan pengenalan ini bukanlah sesuatu yang berpusat kepada ciptaan. Mengenal Allah memiliki tujuan untuk membuat kita menyadari, mengakui, dan menyatakan kemuliaan Allah. Kemuliaan Allah adalah obyek dari pengetahuan ini. ${ }^{38}$ Setiap pengenalan akan Allah harus menuju kepada kesadaran akan kemuliaan Allah sehingga: "...God is glorified in it, as hereby his excellency is seen." 39 Pengenalan akan Allah tidak berfokus kepada keselamatan manusia. Sebaliknya, pengenalan yang menyelamatkan berfokus kepada kesadaran akan kemuliaan Allah, sehingga Allah dipermuliakan. Dengan demikian, orang-orang yang tidak diselamatkan pun, bila menghadapi murka Allah, akan tiba pada pengenalan yang menyadarkan Dia akan keberadaan Allah dan "his excellency is seen", meski tanpa keintiman cinta kasih Tuhan, tetapi berada dalam kedahsyatan murka Allah. Maka, konsep penciptaan dalam pemikiran Edwards harus menuju kepada apa yang Allah nilai sebagai yang ultimat. Apakah yang dapat memiliki kualitas lebih daripada Allah sendiri untuk menjadi yang ultimat?

\section{Doxological Disposition dan Kemuliaan Kristus sebagai Inti dari Natur Doxologi}

Karena tujuan dari penciptaan adalah pernyataan dari kemuliaan Allah, maka tujuan dari penciptaan manusia pun dilakukan untuk hal yang sama. Setiap manusia yang mengalami pengenalan akan Allah dan hidup demi kemuliaan Allah merupakan orang-orang yang telah memiliki tujuan yang berarah kepada hal yang ultimat. Tujuan hidup ini merupakan sesuatu yang didorong oleh suatu dorongan natural dari disposisi yang telah diubahkan. Disposisi yang dimaksud merupakan konsep yang telah dikenal sejak zaman Aristoteles, yaitu konsep hexis, dan Thomas Aquinas (habitus). Edwards memiliki konsep disposisi sebagai suatu...

...active, teleological, and causal power that is also an ontologically real, abiding principle. Habit is a virtual principle that stands at a midpoint between mere potentiality and full actuality. ...And this virtual power and prescriptive pattern belongs not only to the order of knowing but also the order of being. ${ }^{40}$

Di sini keunikan dari pemikiran Edwards, yaitu melihat suatu konsep disposisi sebagai sesuatu yang ontologically real. Yang dimaksudkan di sini adalah Edwards tidak melihat suatu disposisi sebagai sesuatu yang terpisah dari keberadaan aktual. Disposisi bukanlah potensi tanpa aktual, melainkan

\footnotetext{
38 Ibid.

39 Ibid.

40 Lee, The Philosophical Theology of Jonathan Edwards. p. 45.
} 
potensi yang sekaligus juga aktual; disposisi juga bukanlah knowing tanpa being (atau, dalam konteks zaman ini, suatu knowledge tanpa doing), melainkan knowing yang sekaligus juga being. Konsep keberadaan ontologis yang dilihat sebagai suatu disposisi akan mengunci semua kemungkinan seseorang dapat menilai diri sebagai seorang petobat sejati tanpa ada perubahan hidup. Edwards, tentu saja, bukanlah seorang dengan konsep yang sama dengan jemaat Galatia yang tersesat, yang mencari pembenaran mereka dengan segala seremoni dan perbuatan baik. Perbuatan baik tidak memiliki dampak apapun bagi keadaan soteriologis kita. Tetapi Edwards adalah orang yang menggabungkan ontological being sebagai suatu dispositional being, dan demikian menuntut perbuatan baik sebagai sesuatu yang menjadi tanda wajib bagi seseorang yang telah diselamatkan. ${ }^{41}$

Melihat disposisi sebagai suatu habit yang berkaitan dengan being dengan kaitan yang lebih kepada keberadaan, yaitu suatu entitas yang sama, dan bukan hanya kaitan antara dua hal yang saling terpisah tetapi berhubungan - maka kita perlu kembali kepada konsep Roh Kudus menurut Edwards, yaitu sebagai Pribadi yang menyatakan Tritunggal secara ad extra. Maka, sebagai Pribadi yang menyatakan, natur dari karya Roh Kudus dalam ad intra juga akan menjadi natur dari karya Roh Kudus secara ad extra, yaitu natur yang meninggikan Pribadi Kedua Allah Tritunggal, yaitu Yesus Kristus; dan natur ini juga tentulah akan menjadi natur dari karya Roh Kudus bagi orang-orang percaya. Roh Kudus, yang adalah Pribadi Ketiga dari Allah Tritunggal, merupakan repetisi sempurna dari Pribadi Pertama (sekali lagi, secara pembedaan logis ${ }^{42}$ ) dalam kasih dan delight kepada Pribadi Kedua, yaitu Yesus Kristus. Natur yang demikian, yang dimiliki oleh Roh Kudus akan direpetisi lagi dalam diri orang percaya. Konsep ini dapat dipertanggungjawabkan sebagai konsep yang konsisten dengan seluruh pemikiran Edwards karena seluruh ciptaan ini, dalam pemikiran Edwards, merupakan repetisi dari karya ad intra Tritunggal. Dan tentu saja seluruh ciptaan termasuk manusia.

Dalam Injil Yohanes dikatakan bahwa Roh Kudus akan memuliakan Yesus Kristus. ${ }^{43}$ Injil Yohanes juga menyebutkan bahwa ini terjadi karena Roh Kudus menerima berita dari Yesus Kristus, yang mendapat berita tersebut dari Bapa. Maka, dan ini dipahami Edwards dengan suatu konsep pemikiran yang konsisten, Bapa, yang hendak meninggikan Kristus,

\footnotetext{
41 Lihat misalnya pembahasan George Hunsinger, "Dispositional Soteriology: Jonathan Edwards on Justification by Faith Alone," dalam Westminster Theological Journal, vol. 66 no. 1.

42 Penulis sangat tidak nyaman membicarakan Allah Tritunggal dengan cara yang mudah disalahmengertikan sebagai suatu modalisme. Maka, sekali lagi, logical distinction harus ditulis kembali. Edwards sendiri jauh dari tuduhan modalisme atau segala bentuk modalistik monarchianisme. Pembahasan Edwards tentang Tritunggal secara konsep perlu diimbangi dengan membaca karya-karya penginjilan dan penggembalaannya seperti "The Excellency of Jesus Christ," dan "Religious Affections" dimana Allah Anak dan Allah Roh Kudus diberikan penghormatan sebagaimana seharusnya sebagai Pribadi Allah yang Mulia, yang mengatur dan memimpin hidup manusia untuk kemuliaan Allah.

43 Yohanes 16:14
} 
menyatakan firman-Nya untuk meninggikan Anak-Nya. Tetapi apakah Anak Allah mendapatkan kemuliaan karena keberadaan diri-Nya? Ataukah Dia mendapatkan kemuliaan tersebut karena sesuatu yang Dia perbuat? Dengan mengenal Edwards lebih dalam, maka kita akan menjawab bahwa keberadaan diri Kristus, yang tidak mungkin dapat dipisahkan secara disposisi atau secara "being," merupakan keberadaan diri yang mulia yang menyatakan kemuliaan-Nya dengan cara yang paradoks, atau, menggunakan konsep Edwards, "conjunction of diverse excellencies". 44 Edwards melihat hal ini sebagai sesuatu yang perlu mendapat pembahasan yang tuntas. Inilah penyebab Edwards menulis diskursusnya mengenai kemuliaan Kristus.

Dalam diskursus ini, Edwards melihat conjunction of diverse excellencies dalam diri Kristus dalam delapan hal. ${ }^{45}$

Pertama, dalam Pribadi Yesus Kristus terdapat keadilan tak terbatas dan juga anugerah tak terbatas. Kedua, dalam Pribadi Yesus Kristus terdapat kemuliaan tak terbatas dan juga kerendahan hati yang paling rendah (lowest humility). Ketiga, dalam Pribadi Yesus Kristus terdapat "infinite majesty" dan juga "transcendent meekness". Keempat, dalam Pribadi Yesus Kristus terdapat sikap hormat yang paling dalam terhadap Allah dan juga kesamaan dengan Allah. Kelima, dalam Pribadi Yesus Kristus terdapat "infinite worthiness of good" dan juga "the greatest patience under sufferings of evil". Keenam, dalam Pribadi Yesus Kristus terdapat "exceeding spirit of obedience", dan juga dominasi tertinggi atas surga dan bumi. Ketujuh, dalam Yesus Kristus terdapat kedaulatan absolut dan juga "perfect resignation". Kedelapan, dalam Pribadi Yesus Kristus terdapat "selfsufficiency", dan juga "an entire trust and reliance on God"

Hal ini merupakan eksposisinya atas Wahyu 5:5 dan 6 dimana Kristus dinyatakan sebagai Singa dari Yehuda, tetapi Dia juga adalah domba yang yang tersembelih seluruhnya. Fakta kekuatan dan kelemahan inilah yang menjadi dasar mengapa Yesus Kristus merupakan satu-satunya Pribadi dengan kemuliaan yang begitu unik, atau yang memiliki conjunction of diverse excellencies, sebagaimana dikatakan Edwards. Dengan konsep kemuliaan yang muncul dari kekuatan, tetapi juga kelemahan - konsep kemuliaan yang terpancar dari kemuliaan, tetapi juga kehinaan - maka kemuliaan Kristus menjadi satu-satunya kemuliaan yang ditinggikan (dan satu-satunya yang layak ditinggikan) oleh Allah Bapa (Flp 2:9). Dan Roh Kudus, sebagai Pribadi Ketiga, Pribadi yang merepetisi secara sempurna kasih dan delight dari Pribadi Pertama bagi Pribadi Kedua, akan menjadi Pribadi yang merepetisi disposisi yang menyatakan kekaguman, keagungan, penyembahan, dan segala hormat, puji, dan kemuliaan hanya bagi Kristus

44 Edwards, The Excellency of Jesus Christ, dari The Works of Jonathan Edwards, 2 vol, Massachusetts: Hendrickson Publishers, 2000. p. 684.

45 Ibid., p. 681, 682. 
Yesus. Betapa mulianya Dia, yang walaupun begitu agung dan mulia, rela diperlakukan begitu remeh dan hina. Betapa mulianya Dia, yang walaupun Raja diatas segala raja dan menguasai segala sesuatu di bumi dan di surga, rela menaklukkan diri dibawah pemerintahan manusia fana yang hanyalah debu saja. Betapa mulianya Dia, yang walaupun adalah sumber segala keindahan dan hikmat, rela diperlakukan dengan hina dan menjadi kebodohan bagi dunia ini. Betapa mulianya Dia, yang walaupun adalah Penghulu hidup, rela turun ke dalam maut. Kemuliaan ini adalah kemuliaan yang tiada taranya. Tetapi kemuliaan ini adalah kemuliaan yang ditolak oleh kebutaan dosa. Kebutaan yang membuat kita hidup sebagai orang-orang yang mati, dan yang hanya dapat dibangkitkan oleh Roh Kudus, yang akan merepetisi disposisi yang memuliakan Yesus Kristus dalam diri setiap orang yang Dia bangkitkan. Edwards menyebut pengorbanan Kristus yang menyerahkan diri-Nya bagi orang berdosa sebagai suatu tindakan yang menyatakan kemuliaan yang tidak ada taranya. ${ }^{46}$ Karena itu, karya Allah menebus manusia merupakan karya yang menyatakan cinta kasih Allah secara ultimat, sebagaimana dikatakan Pauw, "The work of redemption reveals the depth and ultimate triumph of God's love", 47 dan dari karya penebusan ini, dimana harmonisasi dari karya Allah yang mencerminkan natur dari karya tersebut ad intra, secara ad extra mencapai kesempurnaanNya dalam pernyataan cinta kasih Allah. Namun natur dari karya penebusan tidak hanya sampai kepada pernyataan dari karya tersebut saja, tetapi juga terus mencakup komunikasi, atau repetisi dari natur baru dimana Roh Kudus, demikian dikatakan Pauw, "indwell the soul and create a new habit of love and holiness", ${ }^{48}$ dimana seseorang memiliki natur baru, yang bukan saja penuh cinta kasih surga dan kesucian, tetapi juga memiliki natur yang dapat disebut sebagai "doxological disposition" (disposisi doksologis). Disposisi doksologis ini merupakan suatu natur yang secara alami menyatakan segala kemuliaan bagi Kristus Yesus, suatu disposisi yang direpetisi dari natur dari Roh Kudus, dan merupakan suatu natur yang juga adalah natur dari Roh Kudus sendiri dalam karya ad intra Tritunggal. Ini merupakan suatu pengertian dasar dalam pemberitaan Injil, yaitu menyatakan kemuliaan Yesus Kristus kepada setiap orang yang belum percaya atau yang belum sungguh-sungguh percaya agar mereka boleh mengenal betapa mulianya Kristus yang kita sembah sehingga nama Tuhan boleh dipermuliakan dan keagungan Kristus disembah oleh lebih banyak orang. Inilah yang disebut dengan doxological disposition. Tetapi disposisi ini merupakan sesuatu yang, oleh Edwards, perlu diklarifikasi lebih lanjut karena memiliki sisi yang mencakup perubahan keseluruhan hidup yang bermula dari mengasihi Allah dengan segenap hati.

\footnotetext{
46 Ibid., p. 684.

47 Pauw, The Supreme Harmony of All. p. 119

48 Ibid., p. 155.
} 


\section{Sumber dari Natur Doxologi Menurut Edwards}

Sebagai bentuk dari repetisi, maka Edwards membahas pertobatan dari orang percaya sebagai suatu bentuk pertobatan yang mengubah hidup secara alami, yang dikerjakan oleh Roh Kudus. Pembahasan ini, salah satunya, terdapat dalam traktat Edwards, Religious Affections. Dalam traktat itu Edwards membahas thesis yang dia kemukakan, yaitu bahwa tanpa natur yang diubahkan, tidak akan ada perubahan menyeluruh dari tingkah laku. Atau dalam kalimat Edwards sendiri: "Without a change of nature, men's practice will not be thoroughly changed." $"$

Perubahan natur ini, bila dikaitkan dengan konsep disposisi ontologis yang, demikian dikemukakan Lee, adalah konsep inti dari seluruh bangunan pemikiran Edwards, akan memiliki tempatnya dalam pengertian Edwards mengenai repetisi dari Roh Kudus. Setelah memberikan disposisi yang bernatur doxologis, menyatakan kemuliaan Kristus, maka, untuk konsisten dengan apa yang Edwards katakan mengenai being dan disposition, dimana disposisi adalah being yang secara ontologis tidak mungkin dipisahkan, maka disposisi yang merupakan repetisi dari natur Roh Kudus tidak mungkin memiliki keberadaan yang berbeda dari natur asalnya, yaitu natur Allah. Natur ini tentunya harus dikaitkan dengan konsep moral, bukan dalam hal kuasa atau otoritas ilahi, sehingga keserupaan dengan natur illahi merupakan sesuatu yang secara moral dapat dijelaskan.

Namun repetisi yang kita alami merupakan repetisi ad extra dari karya ad intra Allah Tritunggal, sehingga bila dalam karya ad intra terdapat repetisi secara pembedaan logis dan sempurna, maka dalam karya ad extra terdapat repetisi secara pembedaan temporal, dan yang secara kekal menuju kesempurnaan -tanpa pernah mencapai kesempurnaan Allah yang memiliki jarak yang tak terbatas. Lee menjelaskan konsep ini sebagai berikut:

Every time a transformed self knows and loves God and all things in relation to God, the actuality of that self, as well as the actuality of the known object, is repeated and thus increased. The knowing self's and the known object's relationships became more extensive and multiplied, and thereby their beauty and their being become "bigger". ${ }^{50}$

Tetapi, sebagaimana dibahas oleh Lee, Edwards tidak memiliki konsep yang meniadakan independensi ciptaan. Lee mengatakan: “...the finite habits and laws, though continually dependent upon God, are given a relative and yet real causal function," the created world also help Edwards to maintain a relative and yet real integrity of the creation as a reality distinguishable from the being of

49 Edwards, Religious Affections. Carlisle: Banner of Truth Trust, cetakan ke-6, 1997. p. 318.

50 Lee, The Philosophical Theology of Jonathan Edwards. p. 112.

51 Ibid., p. 107. 
God. ${ }^{, 52}$ Konsep ini menjaga pengertian Edwards dari konsep Pantheistik atau Panentheistik dalam melihat karya Allah. Bergantung, tetapi memiliki integritas sejati. Konsep inilah yang membuat Edwards terus memperjuangkan pemberitaan firman untuk melihat adanya pertobatan sejati terjadi. Konsep repetisi disposisi dari Roh Kudus hanya akan terjadi jikalau firman Tuhan disampaikan dan dosa ditegur. Dengan demikian, Edwards terus bekerja dalam pelayanan mimbarnya, dan juga dengan segenap usahanya untuk memberikan pengertian sejati mengenai kepercayaan sejati dengan menulis traktat-traktat penting mengenai pertobatan sejati, sehingga Roh Kudus memakai setiap firman Tuhan yang disampaikannya untuk merepetisi disposisi yang senantiasa menaikan doxologi bagi kemuliaan Allah. Konsep yang dia terapkan dalam pelayanan mimbarnya dengan kesadaran bahwa Tuhan akan menyertai pelayanannya ini.

Dalam pernyataan kebenaran tesisnya, Edwards membahas perbedaan antara natur dari agama palsu dengan kepercayaan sejati. Meskipun Edwards merupakan seorang yang telah berhasil meninggalkan pola pikir rasionalistik yang populer pada zamannya, ${ }^{53}$ tetapi dia juga bukan seorang yang anti intelektual. Edwards sangat menghargai argumenargumen yang baik, logis, teratur, dan konsisten - dan ini terlihat juga dari tulisan-tulisan maupun khotbah-khotbahnya - dan dengan keinginan untuk membahas segala sesuatu hingga tuntas, maka Edwards membahas natur dari iman sejati yang menjadikan seseorang yakin bahwa dia telah berada dalam anugerah Tuhan. Iman sejati tersebut, demikian menurut pemikiran Edwards, merupakan suatu keadaan dimana natur kita telah berubah menjadi suatu natur baru yang tidak pernah mungkin kita gantikan.

Natur baru ini adalah natur yang menyatakan bahwa keberadaan agama sejati berada pada kemurnian cinta kasih. Edwards mengatakan, "There are false affections, and there are true. A man's having much affection, does not prove that he has any true religion: but if he has no affection, it proves that he has no true religion." 54 Keseluruhan konsep yang dipahami Edwards merupakan konsep yang tidak terlepas dalam setiap aspek kehidupan manusia, terutama yang dia pahami dalam jemaatnya sendiri. Mulai dari pertobatan yang palsu, keangkuhan, ciri-ciri pertobatan yang terlihat, dan golongan antusiasme yang mengabaikan pengenalan sejati. Natur baru ini juga merupakan natur yang diturunkan dari natur Kristus sebagai yang sempurna dan sebagai teladan. Natur ini juga natur yang mengatur seluruh aspek kehidupan manusia dengan mengidentikkan keberadaan diri secara emosi dan afeksi sebagai sesuatu yang mendorong

$52 \quad$ Ibid., p. 108.

53 Ibid., p. 126.

54 Edwards, Religious Affections. p. 50. 
seseorang, entah itu untuk melayani Tuhan, maupun untuk melawan Dia. ${ }^{55}$ Edwards mengatakan bahwa hal yang paling utama adalah adanya kasih akan Allah dalam diri seseorang. Pengetahuan, menurut Edwards, merupakan pengetahuan yang harus mempertimbangkan beberapa hal seperti, hati, cinta kasih, kerinduan senantiasa akan Tuhan. ${ }^{56}$ Tetapi sumber dari natur doksologi merupakan sumber yang berasal dari keberadaan diri yang sudah diubahkan. Perubahan yang begitu mendasar sehingga tidak mungkin seseorang yang belum diubahkan akan secara sempurna dan secara konsisten mampu melakukan perubahan ini terus menerus. Pada akhirnya dia akan kembali melakukan apa yang biasa dia lakukan. Tetapi orang yang telah diubahkan, akan secara alami memiliki hal-hal yang menunjukkan kepercayaan Kristen sejati, sebagaimana dikatakan Edwards:

From a vigorous, affectionate, and fervent love to God will necessarily arise other religious affections; hence will arise an intense hatred and abhorrence of sin, fear of sin, and a dread of God's displeasure, gratitude to God for his goodness, complacence and joy in God when God is graciously and sensibly present, and grief when he is absent, and a joyful hope when a future enjoyment of God is expected, and fervent zeal for the glory of God. And in like manner, from a fervent love to men will arise all other virtuous affections towards men. ${ }^{57}$

Inti dari apa yang mau disampaikan Edwards, yaitu natur dari agama sejati, dinyatakan ketika Edwards mengatakan bahwa kasih kepada Allah tidak mungkin berdasarkan kepada self-love. ${ }^{58}$ Pengertian ini merupakan suatu pengertian yang kembali kepada konsep disposisional yang merupakan karya ad extra dimana karya ad intra menjadi dasarnya; dimana kemuliaan Allah harus menjadi tujuan dari segala karya tersebut, baik pada ad intra maupun ad extra. Memang tidak ada apapun yang memiliki kesempurnaan keindahan dan kesempurnaan moral yang lebih dari Allah sendiri, sehingga tidak mungkin tujuan dari karya tersebut berfokus pada apapun diluar Allah sendiri. Pengertian ini merupakan pengertian yang mengambil konsep dasar pada natur dari moral sejati. Moral sejati adalah moral yang berasal dari Allah, dan tercermin, baik dalam Kitab Suci, ${ }^{59}$ maupun dalam hidup orang Kristen sejati. ${ }^{60}$

Dalam konsep Edwards mengenai moral sejati, terutama banyak tercakup oleh karyanya, "Nature of True Virtue," moral sejati merupakan

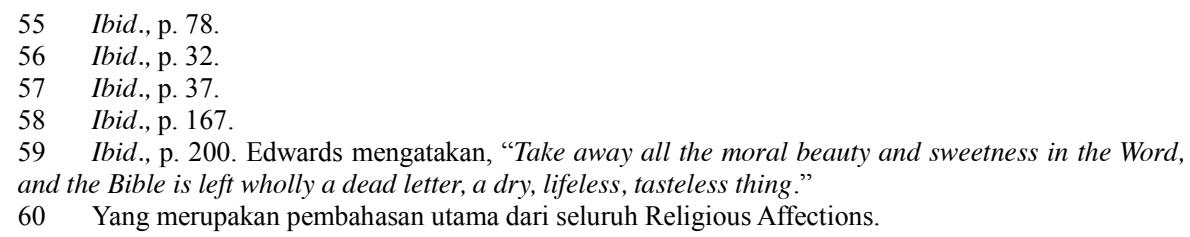


suatu bentuk virtue, atau kebaikan, yang merupakan keindahan dalam lingkup tingkah laku, dimana keindahan itu, sama seperti seluruh keindahan lain dalam ciptaan Allah, memiliki kesempurnaan dalam diri Allah sendiri. Maka natur dari moral sejati adalah natur yang terutama ada dalam bentuk mengasihi Allah, "the Being of beings, infinitely the greatest and best",61 Alasan Edwards akan hal ini lebih jelas lagi dikatakan dalam kalimat berikut:

Because God is not only infinitely greater and more excellent than all other being, but he is the head of the universal system of existence; the foundation of all being and all beauty; from whom all is perfectly derived, and on whom all is most absolutely and perfectly dependent; of whom, and through whom, and to whom is all being and all perfection; and whose being and beauty are, as it were, the sum and comprehension of all existence and excellence: much more than the sun is the fountain and summary comprehension of all the light and brightness of the day. ${ }^{62}$

Seluruh keindahan dan kesempurnaan moral Allah merupakan kesempurnaan yang menjadi acuan bagi setiap tingkah laku moral dari setiap orang yang telah mengalami hidup baru, dan natur yang telah diperbaharui oleh Roh Kudus.

\section{Tradisi Reformed dalam Pelayanan Mimbar}

Jonathan Edwards, sebagai seorang gembala, yang juga mewarisi suatu tradisi reformasi melalui sayap Calvin, tentu memiliki suatu kerinduan agar seluruh jemaatnya memiliki suatu natur yang diubahkan oleh Roh Kudus. Konsep Edwards adalah: "Just as the Spirit's love binds believers together in community, so its presence in the individual must be manifest to the community". 3 . Dia rindu agar Kerajaan Allah dapat dinyatakan dengan makin mulia dalam pelayanannya. Tuhan mengizinkan Edwards mengalami periode kebangunan rohani yang luar biasa, periode "The Great Awakenings," yang berawal pada tahun 1734 (untuk wilayah Edwards) dan memuncak pada tahun $1741 .{ }^{64}$ Sebagaimana telah dibahas sebelumnya, Edwards memiliki konsep kebergantungan mutlak ciptaan kepada Allah dalam bentuk yang, menggunakan istilah Lee, "relative and yet real causal function". Dengan demikian, dengan tidak meniadakan konsep Roh Kudus sebagai Pribadi yang melakukan karya repetisi natur

\footnotetext{
61 Edwards, "Nature of True Virtue," dari The Works of Jonathan Edwards, 2 vol, Massachusetts: Hendrickson Publishers, 2000. p. 125.

62 Ibid.

63 Pauw, The Supreme Harmony of All. p. 166.

64 Edwards mengkhotbahkan salah satu khotbah kebangunannya yang paling terkenal, "Sinner In the Hand of an Angry God" pada tahun 1741. Lebih lengkap dapat melihat kronologi hidup Edwards dalam karya Marsden, Jonathan Edwards: A Life (New Haven: Yale University Press, 2003.
} 
baru dalam pertobatan manusia, tetapi Roh Kudus ini bekerja menggunakan orang-orang yang telah diubahkan. Dengan segenap natur yang telah diubahkan, yang penuh kerinduan untuk mempermuliakan Allah, dengan segenap kesadaran dan kemampuan orang-orang tersebut; Roh Kudus menyatakan karya tersebut melalui firman yang dinyatakan melalui orangorang tersebut. Orang-orang tersebut, dengan kesadaran, kerinduan, penuh ucapan syukur dan bersemangat untuk meninggikan Kristus, menyatakan firman Tuhan dengan sungguh-sungguh. Ini merupakan warisan yang dapat kita telusuri sejauh periode Reformasi Martin Luther. ${ }^{65}$

Konsep pelayanan firman dalam pengertian Luther merupakan suatu konsep yang terus diwarisi dan diperkembangkan dalam tradisi Reformed setelah dia. Luther mengatakan bahwa panggilannya adalah untuk mengkhotbahkan Injil. ${ }^{66}$ Kesungguhan untuk menyatakan Injil dalam diri Martin Luther disertai dengan kepercayaan bahwa Injil akan mengubah segala sesuatu. ${ }^{67}$ Ini merupakan konsep yang menerobos abad-abad dimana gereja tidak lagi menyatakan firman Tuhan. Bahkan dalam periode reformasi ada satu lukisan yang menggambarkan Luther dan salah satu kardinal sedang berkhotbah berhadap-hadapan, dimana pendengar terbagi menjadi dua. Luther mengatakan, "Tuhan berfirman...," sedangkan sang kardinal berkata, "Paus berfirman..." Lukisan ini menggambarkan bahwa keunikan periode reformasi, yang menjadi suatu gerakan yang besar pada masa Luther, menawarkan khotbah yang menyatakan firman Tuhan. Hamba Tuhan harus mengkhotbahkan firman Tuhan. Luther percaya bahwa Roh Kuduslah yang mempertobatkan, tetapi dia percaya juga bahwa Roh Kudus ini tidak mungkin melakukan pekerjaan-Nya tanpa firman. Demikian pemikiran Luther yang dirangkum oleh Paul Althaus: ${ }^{68}$ "The Spirit does not speak without the word" dan "The Spirit speaks through and in the word". Dari pengertian ini, maka karya dari Roh Kudus yang mengomunikasikan karya Allah Tritunggal, dan yang merepetisi disposisi-Nya dalam diri orang percaya, tidak akan terjadi tanpa firman. Demikian juga firman tidak mungkin bekerja dan memiliki kuasa perubahan apa-apa tanpa Roh Kudus. Luther percaya bahwa iman timbul atas pekerjaan Roh Kudus melalui firman, dan Roh Kudus membuat firman memiliki kuasa melalui penyampaian kita; memiliki kuasa untuk menghantam hati manusia. ${ }^{69}$

Tradisi ini kemudian berlanjut dan kita akan melihat pengaruh seorang Reformator yang bukan hanya mewarisi tradisi Reformasi ini dari Luther, tetapi juga yang memberikan reformasi suatu bentuk dan tata gereja

65 Tentu saja tradisi menyatakan firman sedemikian ini tidak dimulai oleh Martin Luther, namun tradisi yang dikenal sebagai "Reformasi" dimulai oleh dobrakan dari Martin Luther pada tahun 1517.

66 Dikutip oleh B. B. Warfield, Selected Shorter Writings, vol 2. New Jersey: Presbyterian \& Reformed, 1970. p. 404.

67 Ibid.

68 Paul Althaus, The Theology of Martin Luther, terj. Robert C. Schultz. Philadelphia: Fortress Press, 1966. p. 36.

69 Ibid., p. 36, 37. 
yang dapat memberikan reformasi suatu kubu yang kuat, konsisten, dan berpengaruh tanpa harus bergantung pada kuasa politik. Dia adalah Calvin. Calvin percaya bahwa firman Allah tidak hanya memiliki kuasa pada waktu pertama kali diberikan, tetapi kuasa tersebut akan terus menyertai pada penyampaian-penyampaian selanjutnya. ${ }^{70}$ Calvin juga memberikan tempat tertinggi kepada Alkitab hanya bila, dan hanya karena Alkitab dilihat sebagai firman Allah, dimana Kristus, Hikmat Allah, adalah sebagai inti beritanya. ${ }^{71}$ Karena itu firman tidak dapat dipisahkan dari Kristus, karena Kristus adalah satu-satunya School-Master of the Church, dan melalui firman gereja diberikan kesempurnaan dari ajaran Kristus. ${ }^{72}$ Karena percaya kepada hal-hal inilah Calvin berkhotbah.

Edwards mewarisi tradisi mimbar dari para tokoh reformasi ini dengan menggabungkan konsep, baik yang dipopulerkan oleh Luther, maupun yang dipopulerkan oleh Calvin. Dari Luther Edwards mewarisi konsep karya Roh Kudus yang menjadikan firman Tuhan berkuasa, dan karya Roh Kudus yang Dia kerjakan melalui firman Tuhan. Roh Kudus menyatakan karya ad intra Allah Tritunggal secara ad extra ${ }^{73}$ dan karena itu Roh Kudus pulalah yang menginspirasikan firman Tuhan menjadi firman yang tertulis. Karya Roh Kudus juga terus berlanjut dengan merepetisi disposisi yang menyatakan kemuliaan Allah melalui mengagungkan Yesus Kristus pada orang-orang sehingga orang-orang berdosa menjadi orang-orang percaya. Roh Kudus ini bekerja melalui firman Tuhan, dan Edwards, yang juga meneruskan konsep dari Luther ini dengan kepercayaannya kepada firman sebagai sarana Roh Kudus untuk bekerja, ${ }^{74}$ adalah orang yang mengizinkan Roh berkarya dengan seluas mungkin dengan kesetiaannya meninggikan dan menyatakan firman Tuhan.

Edwards juga meneruskan Calvin dengan konsep natur doxologi dari Roh Kudus yang meninggikan Kristus. Penyampaian firman Tuhan seharusnya berfokus pada meninggikan Kristus dan Kristus yang ditinggikan ini dinyatakan oleh orang dengan sifat yang sama dengan sifat ilahi, yaitu sifat yang direpetisi dari natur Roh Kudus sendiri, yang meninggikan Kristus. Khotbah-khotbah Edwards merupakan suatu dorongan untuk meninggikan Kristus dengan seluruh keberadaan seseorang. Edwards percaya pada pola kebangunan yang dikerjakan Allah pada masa di mana terjadi kelesuan rohani, meskipun dia tidak menganggap bahwa dirinya dapat mengetahui kapan waktu dimana Tuhan akan bekerja; dan seluruh khotbahnya merupakan suatu dorongan bagi orang-orang untuk

70 T. H. L. Parker, Calvin's Preaching. Louisville: Westminster/John Knox Press. p. 24. Tentu saja Calvin tidak menganggap setiap kali firman disampaikan -yaitu dalam bentuk khotbah- adalah sama dengan pemberian firman pertama kali -dengan otoritas inspirasional- karena Calvin dengan tegas mengingatkan untuk tidak mengangkat khotbah ke level inspirasional. Lihat Parker, p. 23.

71 Ibid., p. 6. Lihat juga argumen mengenai penerimaan Alkitab sebagai wahyu Allah pada p. 2.

72 Ibid., p. 6, 7.

73 Pembahasan pada p. 4.

74 Edwards, Religious Affections. p. 184. 
kembali kepada Allah. ${ }^{75}$ Dengan beban untuk melihat kemuliaan Allah terus direpetisi dalam sejarahlah Edwards berkhotbah, meninggikan Kristus, dan membiarkan Roh Kudus bekerja merepetisi disposisi doxologikal-Nya pada setiap orang yang merupakan umat pilihan Tuhan.

Selain pembahasan diatas, dalam melihat konsep khotbah Edwards, juga harus dilihat keseluruhan konsep yang dia miliki tentang natur ciptaan yang terus berada dalam keadaan dinamis untuk menyatakan repetisi dari God's internal glory. Hal ini berarti bahwa konsep disposisi yang direpetisi untuk memuliakan Allah merupakan konsep yang holistik. Memang benar Edwards mengatakan bahwa tanpa afeksi sejati tidak akan ada agama sejati, tetapi Edwards juga tidak meniadakan konsep berpikir yang menggunakan rasio dan proposisi-proposisi yang ketat dan konsisten. Khotbah Edwards adalah khotbah yang memiliki ciri Puritan yang dengan ketat menggunakan argumen-argumen pendukung dari satu atau beberapa poin yang menjadi pendukung satu tema utama dari sebuah khotbah. Edwards bukanlah seorang anti intelektual, tetapi dia adalah seorang pewaris Calvin, dan Calvin sendiri merupakan seorang pengkhotbah yang, demikian menurut John Leith, memiliki tipe khotbah yang merupakan "an intellectual exercise and a mental discipline that had a significant cultural impact". Namun disisi lain, Calvin juga "intellectualistic". Leith menggambarkan, "The learning that was joined to piety had a strong pragmatic and utilitarian quality. ${ }^{76}$ Siapapun yang pernah membaca teks khotbah Edwards akan setuju bahwa penggambaran mengenai Calvin diatas juga adalah penggambaran yang tepat jika diterapkan untuk mendeskripsikan Edwards. Penggabungan yang unik ini merupakan suatu pemahaman atas natur disposisi yang mencakup keseluruhan keberadaan. Disposition as being.

\section{Tradisi Reformed dan Konsep Pusat dan Pinggiran dalam Pelayanan Mimbar}

Komunitas Kristen merupakan komunitas yang hidup, mewarisi suatu tradisi yang begitu agung dan harus memahami sebuah tradisi sebagai tradisi yang hidup dan terus diwariskan. Sebuah tradisi menjadi tradisi yang mati ketika tradisi tersebut menjadi dibakukan dan diambil secara legalistik. Tradisi tersebut menjadi "no longer alive but dead and fit only for sterile repetition". ${ }^{77}$ Tetapi, ketika inti dari tradisi dapat terus dipelihara, maka tradisi tersebut akan menjadi tradisi yang hidup dan diwariskan dengan dinamis, sehingga pada setiap zaman Kekristenan dapat menjadi pemimpin zaman, walaupun minoritas. Tetapi pengertian ini harus dimengerti dalam konsep yang luas. Tradisi yang diwariskan secara hidup dan dinamis adalah

75 Lihat pembahasan dari Helen Westra dalam Edwards in Our Time, Sang Hyun Lee dan Allen C. Guezlo, ed. Grand Rapids: Eerdmans, 1999.

76 John Leith, Introduction to the Reformed Tradition. Atlanta: John Knox Press, 1981. p. 81.

77 Ibid., p. 29. 
tradisi yang dimengerti sebagai suatu zeitgeist dimana Allah menyatakan pekerjaan-Nya dalam sejarah. Pekerjaan yang dikerjakan Allah adalah pekerjaan yang berfokus kepada menyatakan Kristus sebagai pusat. Warisan tradisi inilah yang menjadi suatu harta berharga yang diterima, diperjuangkan, dan diwariskan oleh Kekristenan sepanjang sejarah. Kekristenan yang tidak mengerti asal sejarahnya merupakan Kekristenan kontemporer yang tidak berakar dan akan segera lenyap seiring dengan berubahnya tren berpakaian. Tetapi Kekristenan yang melihat sejarah tanpa menyadari signifikansinya bagi zaman kontemporer akan menjadi Kekristenan yang mati dan mewariskan tradisi legalistik yang mati kepada generasi selanjutnya. Kedua kubu ini tidak mungkin menggambarkan tradisi Kristen yang sejati. Tetapi tradisi Kristen yang mewarisi semangat gerakan, menangkap inti dari sejarah, dan memperjuangkannya pada zamannya adalah tradisi Kristen yang sejati.

Apakah berlebihan bila penulis katakan bahwa tradisi Reformed memiliki hal ini? Penulis tidak sedang berkata bahwa apa yang terjadi sepanjang sejarah Reformasi hingga diwariskan hingga reformed saat ini merupakan suatu pelajaran sejarah yang harus dibakukan dan dianggap tak mungkin salah, namun, sebagaimana diakui oleh John Leith:

The reformed tradition does not claim to be the only Christian tradition. It does not claim to be one way the one, holy, catholic, apostolic church has lived, handing on its faith and life to every new generation. It does claim to be an authentic form of the Christian community that has its special strength but also weakness and problems. It tends to be the people of God in all their fullness. On the basis of this claim, it asks for both acceptance and criticism. ${ }^{78}$

Dengan memahami tradisi Reformed sebagaimana tujuannya yang terus menerus diwariskan, yaitu, meminjam penjelasan Leith, untuk menjadi "the people of God in all their fullness", maka Reformed memiliki suatu tradisi yang, tidak terbantahkan, dipakai Tuhan untuk menyatakan begitu banyak pelajaran berharga bagi setiap zaman. Bila berfokus kepada apa yang Edwards wariskan, maka, harus diakui, Edwards sendiri saja sudah memberikan dobrakan yang melampaui zamannya yang hingga kini terus mempengaruhi zaman. Dengan berfokus kepada konsep Edwards, penulis rindu agar tradisi reformed, dengan mengambil segala kekuatan darinya sambil berhati-hati pada kelemahannya, boleh menjadi suara yang dapat kembali menyadarkan gereja mengenai satu bidang kehidupan bergereja yang sangat penting, yaitu mimbar. Tradisi Kekristenan tidak pernah lepas dari pengaruh yang diberikan dari atas mimbar. Leith mengatakan bahwa senjata untuk membentuk suatu komunitas Kristen untuk menjadi 
komunitas yang membentuk kehidupan komunitas lebih besar dimana komunitas Kristen itu ada adalah firman Tuhan. ${ }^{79}$ Prinsip mimbar dari konsep disposisi doksologis Edwards memberikan suatu sumbangan yang besar bagi kelanjutan tradisi Kristen. Roh Kudus merepetisi disposisi ini dalam diri orang percaya melalui firman. Dengan demikian, seorang pengkhotbah harus merupakan seseorang yang telah mengalami perubahan ini, yang secara natural memiliki kerinduan untuk meninggikan Kristus, dimana kerinduan ini adalah kerinduan yang muncul dari perubahan natur yang sejati, sebagaimana prinsip afeksi sejati dari Edwards. Kerinduan ini membuat sang pengkhotbah sadar bahwa dia sedang menaikkan suatu doxologi setiap kali dia berkhotbah menyampaikan firman Tuhan. Jika seseorang hendak meninggikan Kristus dalam khotbahnya dan dalam hidupnya, maka orang tersebut harus ingat kemuliaan Kristus. Dia yang paling layak mendapatkan segala puji dan hormat ternyata juga adalah Dia yang rela dihina, dicaci-maki, dan diberikan tempat yang sangat rendah dalam hidup-Nya di dunia. Inilah the excellency of Christ sebagaimana ditulis dalam salah satu discourse Edwards, sebagaimana telah dibahas di atas. Maka jika Kristus yang mulia rela untuk mengalami kehinaan, apakah layak bila seorang pelayan mimbar mencari untuk dipermuliakan? Bukankah mimbar dapat menjadi tempat mencari pengakuan? Bukankah mimbar dapat menjadi tempat dimana sang pengkhotbah dapat tergoda untuk mengambil semua fokus perhatian yang sebenarnya hanya layak diberikan kepada Kristus, yang ditinggikan oleh Allah sendiri?

Dalam sebuah artikelnya, Miroslav Volf membahas tentang ketidakmungkinan gereja menjadi pusat dari suatu masyarakat pluralistik. ${ }^{80}$ Ini disebabkan karena setiap bidang telah memiliki pusat mereka sendiri sehingga gereja tidak mungkin dapat lagi mewujudkan mimpi untuk kembali pada abad pertengahan dimana gereja menjadi sang ratu untuk segala bidang. Tetapi alasan yang kemudian diberikan Volf adalah alasan yang lebih tepat. Alasan tersebut adalah karena memang bukan kita yang harus menjadi pusat. Kristuslah yang menjadi pusat, maka kita, orang-orang Kristen, biarlah kita menjadi orang yang meminggirkan diri sendiri. ${ }^{81}$ Karena Kristus yang menjadi pusat diatas mimbar, maka biarlah sang pengkhotbah menjadi orang yang meminggirkan diri sendiri.

Konsep Edwards mengenai disposisi yang direpetisi untuk memuliakan Kristus merupakan suatu warisan tradisi yang harus diperjuangkan dalam setiap zaman. Tidak seorangpun boleh berdiri diatas mimbar sebuah gereja dengan disposisi yang meninggikan dan mengagungkan diri sendiri. Disposisi ini bukan direpetisi dari Roh Kudus.

$79 \quad$ Ibid., p. 78.

80 "Theology, Meaning, and Power," sebuah tulisan Miroslav Volf dalam The Future of Theology: Essay in Honor of Jurgen Moltmann, Miroslav Volf, Carmen Krieg, Thomas Kucharz ed. Grand Rapids: Eerdmans, 1996. p. 110.

$81 \quad$ Ibid., p. 111. 
Entah direpetisi dari mana. Dan karena penulis tidak ingin menyebut direpetisi dari setan - ini tidak ada dalam konsep Edwards - maka biarlah penulis mengatakan bahwa peninggian diri merupakan suatu natur yang terus merepetisi diri, berasal dari diri yang jatuh ke dalam dosa, dan memuncak pada keangkuhan yang pada akhirnya membawa seseorang kepada kebinasaan. Repetisi sejati dari disposisi Roh Kudus membuat seseorang meninggikan Kristus sebagai sesuatu yang secara natural mengalir dari dalam dirinya. Dia tidak harus berpura-pura, dan dia tidak harus merasa tidak nyaman. Tetapi seperti inilah keberadaan sejati orang tersebut. Dan keberadaan sejati ini tidak mungkin muncul hanya ketika seseorang khotbah, lalu hilang ketika dia turun dari mimbar. Seperti Roh Kudus yang memiliki natur yang meninggikan Kristus, demikianlah setiap pengkhotbah yang naik mimbar seharusnya memiliki repetisi dari natur ini dalam dirinya. Biarlah setiap zaman boleh meneruskan dan memperjuangkan tradisi ini, yaitu tradisi yang mengatakan Kristus harus semakin bertambah, dan kita harus semakin berkurang.

\section{BIBLIOGRAFI}

Althaus, Paul. The Theology of Martin Luther, terj. Robert C. Schultz. Philadelphia: Fortress Press, 1966.

Edwards, Jonathan. "Nature of True Virtue", dari The Works of Jonathan Edwards, 2 vol. Massachusetts: Hendrickson Publishers, 2000.

Edwards, Jonathan. "The End for which God Created the World", dari The Works of Jonathan Edwards 2 vol. Massachusetts: Hendrickson Publishers, 2000.

Edwards, Jonathan. "The Excellency of Jesus Christ", dari The Works of Jonathan Edwards, 2 vol. Massachusetts: Hendrickson Publishers, 2000.

Edwards, Jonathan. Religious Affections. Carlisle: Banner of Truth Trust, cetakan ke-6, 1997.

Holmes, Stephen R. God of Grace and God of Glory. Grand Rapids: Eerdmans, 2000.

Holmes, Stephen. God of Grace and God of Glory. Grand Rapids: Eerdmans, 2000.

Hunsinger, George. Dispositional Soteriology: Jonathan Edwards on Justification by Faith Alone, dalam Westminster Theological Journal

Leith, John. Introduction to the Reformed Tradition. Atlanta: John Knox Press, 1981.

Marsden. Jonathan Edwards: A Life. New Haven: Yale University Press, 2003.

Nichols, Stephen J. An Absolute Sort of Certainty: The Holy Spirit and the Apologetics of Jonathan Edwards. New Jersey: Presbyterian \& 
Reformed, 2003.

Parker, T. H. L. Calvin's Preaching. Louisville: Westminster John Knox Press, 2006.

Pauw, Amy Plantinga. The Supreme Harmony of All: The Trinitarian Theology of Jonathan Edwards. Grand Rapids: Eerdmans, 2002.

Sang Hyun Lee. "Jonathan Edwards's Dispositional Conception of the Trinity", dari Toward the Future of Reformed Theology: Tasks, Topics, Traditions. David Willis, Michael Welker, eds. Grand Rapids: Eerdmans, 1999.

Sang Hyun Lee. The Philosophical Theology of Jonathan Edwards. New Jersey: Princeton University Press, 1988.

Volf, Miroslav. "Theology, Meaning, and Power", The Future of Theology: Essay in Honor of Jurgen Moltmann. Miroslav Volf, Carmen Krieg, Thomas Kucharz, eds. Grand Rapids: Eerdmans, 1996.

Warfield, B. B. Selected Shorter Writings, vol 2. New Jersey: Presbyterian \& Reformed, 1970.

Westra, Helen. Edwards in Our Time. Sang Hyun Lee dan Allen C. Guezlo, eds. Grand Rapids: Eerdmans, 1999. 